\title{
Ediacaran to Cambrian oceanic rocks of the Gondwana margin and their tectonic interpretation
}

\author{
Jürgen F. von Raumer • Gérard M. Stampfli • \\ Ricardo Arenas $\cdot$ Sonia Sánchez Martínez
}

Received: 22 October 2014 / Accepted: 4 January 2015 / Published online: 24 January 2015

(C) Springer-Verlag Berlin Heidelberg 2015

\begin{abstract}
In tectonic maps of Variscan Europe, allochthonous pieces of Cadomian basement clearly stand out with their predominant metabasic to ultrabasic elements, the so-called exotic terranes with ophiolites. Most of these domains are observed in basements of the Central Iberian Allochthone, the South Armorican domain, the nappe structures of the French Massif Central, the Saxothuringian Zone and the Bohemian Massif. Similar relics can be recognized in many Alpine basement areas, and correlations with supposedly more autochthonous basements, such as the Ossa Morena Zone and the Central Iberian basement, can be envisaged. All of these relics are thought to represent the interrupted trace of a former continuous or discontinuous structure, characterized by the presence of oceanderived proto-Rheic rock suites. These can be interpreted as pieces of former magmatic arcs of Ediacaran to Cambrian age accreted to the Gondwana margin, which later were scattered as allochthonous units during the Variscan platetectonic processes. The presence of similar rock suites of
\end{abstract}

J. F. von Raumer $(\bowtie)$

Dépt. de Géosciences, Université de Fribourg,

1700 Fribourg, Switzerland

e-mail: Juergen.vonraumer@unifr.ch

G. M. Stampfli

Earth Sciences Institute (ISTE) Geopolis, UNIL,

1015 Lausanne, Switzerland

e-mail: gerard.stampfli@unil.ch

R. Arenas · S. Sánchez Martínez

Departamento de Petrología y Geoquímica and Instituto de Geociencias (UCM, CSIC), Universidad Complutense de Madrid, 28040 Madrid, Spain

e-mail: arenas@geo.ucm.es

S. Sánchez Martínez

e-mail: s.sanchez@geo.ucm.es
Ordovician age in the Alpine realm is explained by the accretion of exotic China-derived basements and their collision with the Gondwana margin during the opening of the Rheic Ocean.

Keywords Neoproterozoic-Cambrian · Geodynamic reconstruction · Gondwana margin · Correlation with western Gondwana

\section{Introduction}

The Palaeozoic Gondwana margin and its interaction with Laurentia-Baltica are strongly related to the history of the Rheic Ocean (Nance et al. 2010; Stampfli et al. 2013). Distinct interpretations have been envisaged for the European Variscan context (Ballèvre et al. 2009; Martínez Catalán et al. 2009; Linnemann et al. 2007; Stampfli et al. 2011), involving models of early interaction with Laurentia-Baltica, the accretion of proto-Rheic intra-oceanic pieces, or only Gondwana-derived terranes, and the formation of the Rheic Ocean was seen either as an intracontinental rift zone or as a widely stretching oceanic space.

Although great progress has been made in the interpretation of the Variscan plate-tectonic evolution (Kroner and Romer 2013; Ballèvre et al. 2014; Lardeaux et al. 2014; Schulmann et al. 2009), the plate-tectonic interpretation of the Variscan basement domains hosting the so-called exotic terranes with ophiolites drawn in Fig. 1a did not change.

The pre-existing omnipresent Cadomian basement (e.g. Linnemann et al. 2007) appears as relics in the highly transformed Variscan basement, and in this framework, we hypothesize the "exotic terranes with ophiolites" (Fig. 1a), and some adjacent autochthonous basements, to represent remnants of a former continuous or 
discontinuous suture zone. The latter can be characterized through the presence of ocean-derived rock suites, which are probably representing pieces of a former continuous magmatic arc of Ediacaran to Cambrian (proto-Rheic) age accreted to the Gondwana margin before being dissipated as allochthonous units during the Variscan plate-tectonic processes.

Our arguments are based on the singular distribution of these units when placed in an already published Early Palaeozoic reconstruction (Stampfli et al. 2011): In tracing terranes back to their possible position around Gondwana, obviously, not all could be positioned north of Africa. The new concept proposes a ribbon-like Galatian superterrane, comprising most of the "European" Variscan elements and extending in Ordovician times from the north of South America to South China (located formerly in continuity to Africa). Evidently, along such a length, the geodynamic evolution presents variations. Instead of terminating the considerations at the Tornquist Line, the hitherto used model and knowledge from the Altaids (Wilhem et al. 2012) let us adopt geodynamic scenarios for the extended Gondwana margin including the Chinese basement areas thus reviving the discussion by von Raumer et al. (2002) and Kalvoda and Bábek (2010). In this enlarged frame, we want to demonstrate, that the allochthonous "exotic terranes with ophiolites" (presented in Fig. 1a) could represent the relics of a former Ediacaran-Cambrian active margin setting along the Gondwana margin, also comprising pieces of Chinese blocks, usually ignored in general considerations.

\section{Ediacaran-Cambrian elements}

In the European geodynamic context, the so-called allochthonous domains with ophiolites (Arenas et al. 2007a, their Fig. 1) basements hosting Ediacaran-Cambrian mafic to ultramafic rock suites (Fig. 1a) appear above the Central Iberian basement, possibly in the South Armorican zone and in the Limousin domain of the French Massif Central, in the Saxothuringian, the Teplá-Barrandian of the Bohemian Massif, and in comparable Cambrian-Neoproterozoic elements from the Alpine domains (e.g. Austroalpine and Briançonnais), all supposed to host mafic and/or ultramafic rock units predating the opening of the Rheic Ocean. Additionally, the Neoproterozoic-Cambrian metabasites from the Ossa Morena Zone and the Central Iberian basement are included in our considerations.

We present in the following lines only the above mentioned basements, proceeding from the most western located Ossa Morena Zone to the most eastern located Alpine domains, independent of their Variscan evolution (comp Table 1):
Fig. 1 Geodynamic units hosting allochthonous "exotic" terranes with ophiolites as relics of former Ediacaran-Cambrian Geodynamic units from the Gondwana margin. a Late Variscan geological map modified after Arenas et al. (2007a). b, c Late Variscan (b) and Hirnantian (c) plate-tectonic reconstructions, modified after Stampfli et al. (2011). Stars (black and violet) meta-eclogites; Crosses autochthonous, low-grade rift-related magmatic rocks. Light blue Avalonian basements; Light brown Rhenohercynian domain. A-A': Section $450 \mathrm{Ma}$ in Fig. 4. Ad Adria and Sardinia, All Allochthonous above the Iberian basement, al-Sx allochthonous Saxothuringian, An Anatolic, AP Aquitaine Pyrenees and Corsica, Ar Armorica, ArS South Armorica, Au Austroalpine, Bri Briançonnais, BRK Betics-RifKabbilies, $B w$ Brunswick, $C a$ Cantabrian and West Asturian-Leonese zones, $C C$ Caucasus, $C h$ Channel, $C h R$ Chamrousse, $c I$ Central Iberia, $C r$ Carpathian, $C t$ Catalunia, $D b$ Dobrogea, $D-B$ Dacides-Bucovinian, $e M$ Eastern Moroccan Meseta (interpreted after Herbig and Aretz (2013, with references), Gt Getic nappes, He External Alpine massifs, $H I$ Hellenidic, Is Istanbul, $L i$ Ligerian block, Md Moldanubian (Black Forest and Vosges included) and Teplá-Barrandian, $M C$ French Massif Central, Me Moroccan Meseta, Mg Meguma, MM Montagne Noire-Maures and Tanneron, Mo Moesia, MR Mid-German Rise, OM Ossa Morena, Po south Portuguese, Pt Pontides (Karakaya), $R d$ Rhodope, $S h$ Sehoul block, $S x$ Saxothuringian domain, $T B$ Teplá-Barrandian unit of the Bohemian Massif, $T W$ Tauern Window, $T z$ Tizia

\section{Ossa Morena Zone}

Two rift-related magmatic events (Sánchez-García et al. 2008; Chichorro et al. 2008; Pereira et al. 2012), comprising an Early Cambrian magmatic cycle dominated by calc-alkaline felsic rocks followed by a Middle Cambrian to Early Ordovician magmatic suite with bimodal alkaline and tholeiitic magmatic rocks, were interpreted as the opening and subduction of a Late Cambrian to Ordovician oceanic ridge (Sánchez-García et al. 2010), after Cambeses et al. (2014) a Cambro-Ordovician rifted volcanic margin. Sánchez Lorda et al. (2014a, b) identify the metabasic series hosted by the Serie Negra metasediments as a Late Ediacaran magmatic arc.

The allochthonous units above the Central Iberian Zone

Derived from peri-Gondwanan regions, they include the Variscan suture s.l. outlined by a suite of Devonian ophiolitic units.

In the northern allochthonous domain, the uppermost terrane is formed by a thick sequence of Cambrian siliciclastic rocks intruded by large massifs of gabbros (Monte Castelo gabbro) and granitoids (Corredoiras orthogneiss) dated at $\sim 500$ Ma (Abati et al. 1999; Andonaegui et al. 2012). The contemporaneous intermediate pressure tectonothermal evolution was followed by a high-pressure and high-temperature event dated at c. $400 \mathrm{Ma}$ (Abati et al. 2007; Fernández-Suárez et al. 2007). In the underlying Variscan "suture", two main types of ophiolites have been described: a younger group with Devonian ages and an older group dated at ca. $500 \mathrm{Ma}$. From the latter, Sánchez 


\section{The European Variscan domains and their geodynamic characteristics}

modified after Arenas et al. 2007
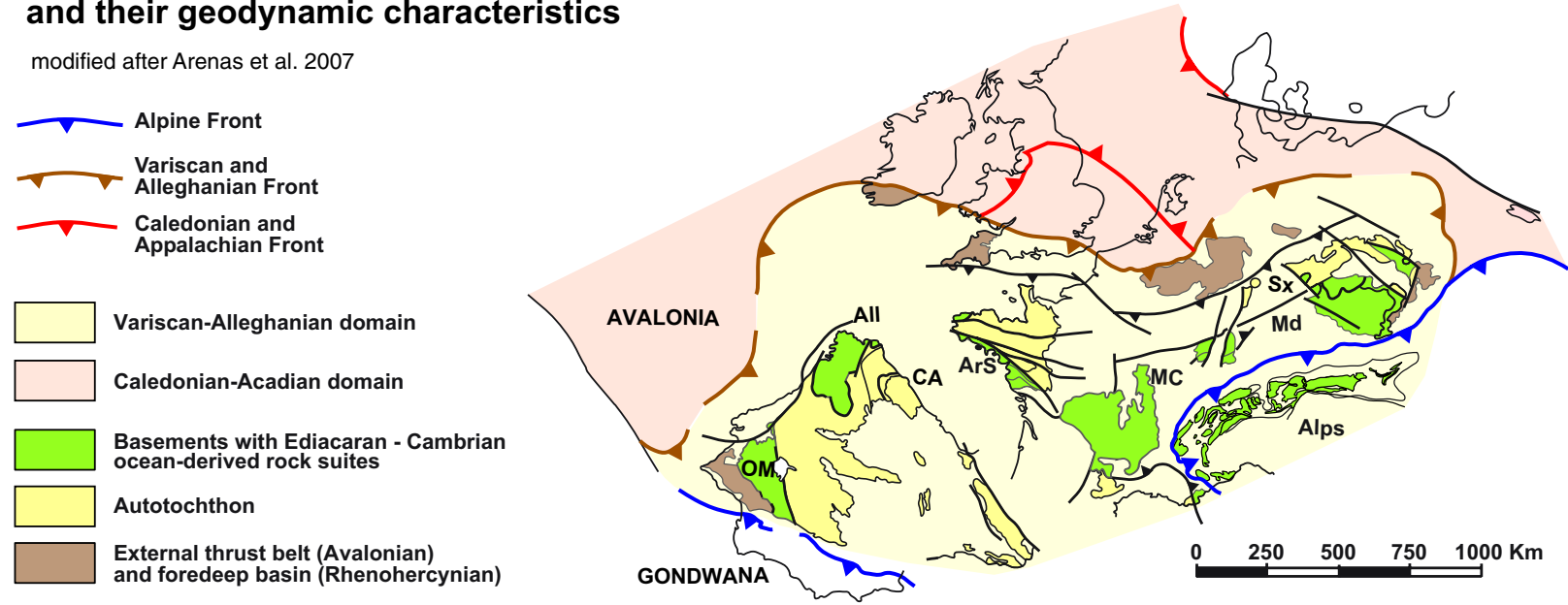

A

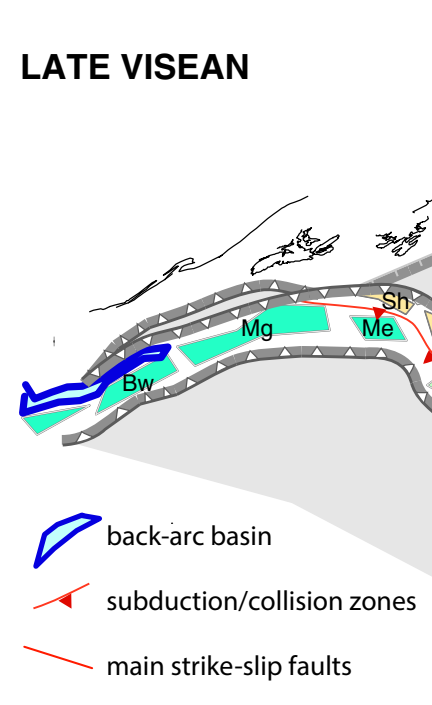

B

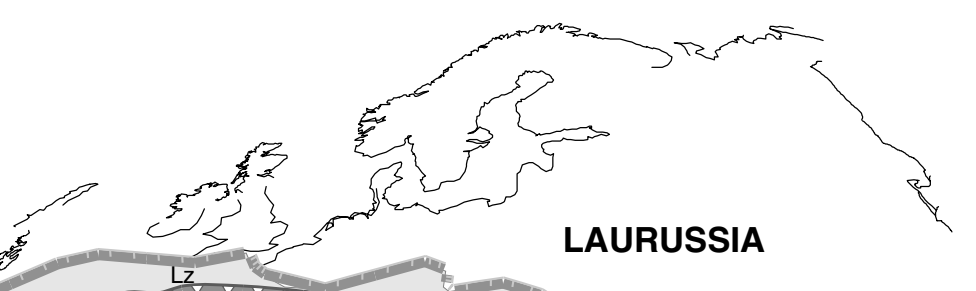

\section{LAURUSSIA}
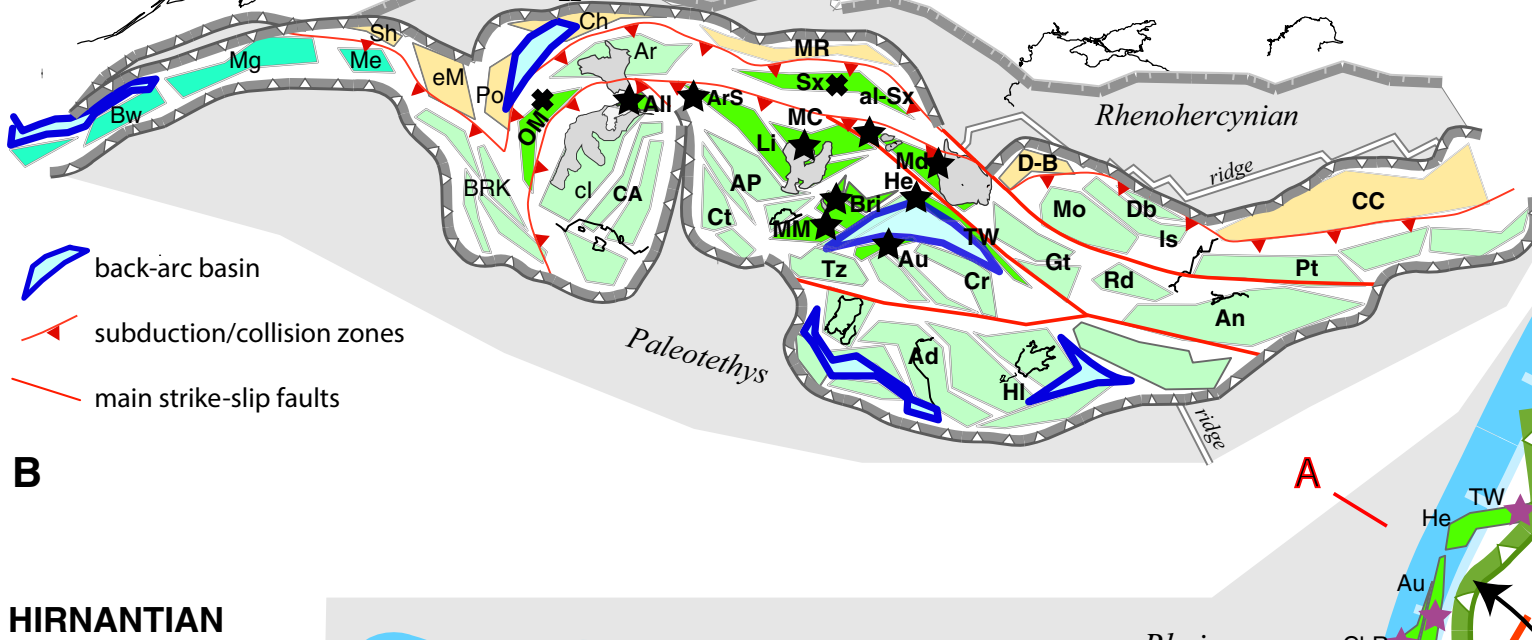

C
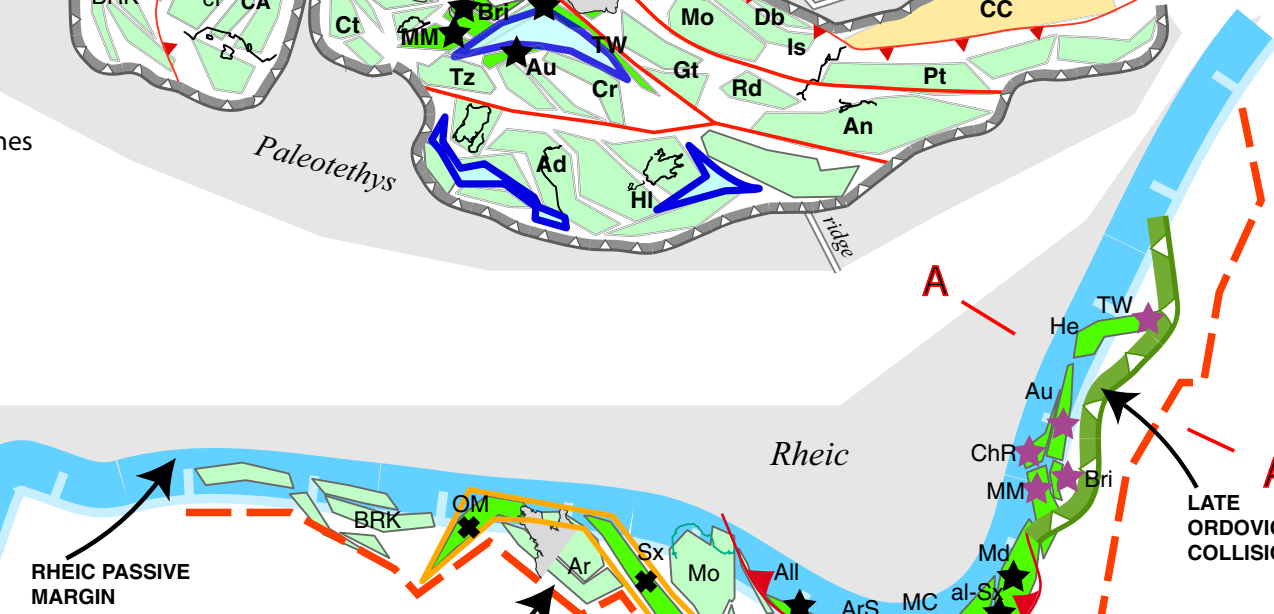
Table 1 Ediacaran-Cambrian ages of metabasic and ultramafic rocks along the Gondwana margin (for older references, see Neubauer 2002, von Raumer et al. 2002)

\begin{tabular}{|c|c|c|c|}
\hline Terrane & Rock-type & Age (Ma) & References \\
\hline \multirow[t]{3}{*}{ 1. Ossa Morena } & Felsic volcanics early rift & $(\sim 530)$ & Sánchez-García et al. (2010) \\
\hline & Main rift basalts & 502 & \\
\hline & Amphibolites N-MORB, E-MORB, VA & $\sim 580 \varepsilon \mathrm{Nd}+0.8$ to +8.4 & Sánchez Lorda et al. (2014) \\
\hline \multicolumn{4}{|l|}{ 2. Central Iberia } \\
\hline \multirow[t]{5}{*}{ Allochthon } & Monte Castelo gabbro & $499 \pm 2$ & Abati et al. (1999) \\
\hline & Vila de Cruzes ophiolite, N-MORB & $497 \pm 4$ & Arenas et al. $(2007 a, b)$ \\
\hline & Bazar ophiolite & $495 \pm 2$ & Sánchez Martínez et al. (2012) \\
\hline & Malpica Tuy eclogites & 494,498 & Abati et al. (2010) \\
\hline & Eclogite protolith & $\sim 491$ & Roper et al. (2013) \\
\hline Autochthon Tamames & Neoproterozoic-lowermost Cambrian metaandesites & Lithostratigraphy & Rodríguez Alonso et al. (2004) \\
\hline 3. South Armorica & Granitoids, gabbros & 480,470 & Ballèvre et al. (2014) \\
\hline \multicolumn{4}{|l|}{ 4. French Massif Central } \\
\hline Marvejols & Bimodal volcanics & $\sim 480$ & Pin and Lancelot. (1982) \\
\hline Limousin & Eclogite, N-MORB tholeiite & $489-475$ & Berger et al. $(2010,2012)$ \\
\hline Massif de Maures & Supra-subduction lithosphere & Early Palaeozoic & Bellot et al. (2010) \\
\hline \multicolumn{4}{|l|}{ 5. Alps } \\
\hline \multirow[t]{6}{*}{ External domain } & Chamrousse oceanic granite & 498 & Ménot et al. (1988) \\
\hline & Chamrousse oceanic granite & 500 & Pin and Carme (1987) \\
\hline & Aarmassif, gabbro & $475-467$ & Oberli et al. (1994) \\
\hline & Aarmassif, gabbro & $478 \pm 5$ & Schaltegger et al. (2003) \\
\hline & HT stage & $456-450$ & \\
\hline & Cordierite-pegmatite & $445 \pm 2$ & \\
\hline \multicolumn{4}{|l|}{ Penninic domain } \\
\hline \multirow[t]{4}{*}{ Briançonnais } & Thyon granite & $500+3 /-4$ & Bussy et al. (1996) \\
\hline & Metagabbro, & $504 \pm 2$ & Sartori et al. (2006) \\
\hline & Cambro-Ordovician & Lithostratigraphy & \\
\hline & Oceanic metabasites & & \\
\hline Métailler formation & Gabbros, tholeiites E-MORB & 457, 462 detrital zircon 520 & Gauthiez et al. (2011) \\
\hline \multirow[t]{2}{*}{ Berisal unit } & Tholeiitic amphibolites & $546 \pm 21 \mathrm{Sm} / \mathrm{Nd}$ wh.r & Stille and Tatsumoto (1985) \\
\hline & Gabbro & $475 \varepsilon N d+5.4$ & \\
\hline \multirow[t]{2}{*}{ Biasca-Loderio } & Mafics-ultramafics IA/T-MORB & $\sim 5187.3$ to 4.2 & Schaltegger et al. (2002) \\
\hline & Sasso Nero metadiorites & 533,544 & Bussien et al. (2011) \\
\hline Adula Salahorn & Back-arc tholeiites & $514-518$ & Cavargna-Sani et al. (2014) \\
\hline Adula Treskolmen & MORB tholeiite affinity & 521.1 & Cavargna-Sani et al. (2014) \\
\hline \multicolumn{4}{|l|}{ Austroalpine domain } \\
\hline \multirow[t]{4}{*}{ Silvretta nappe } & Gabbro & 475,510 & Poller (1997) \\
\hline & Arc metadiorites & $\sim 610$ & Schaltegger et al. (1997) \\
\hline & Metagabbros, metatonalites & 523 & Schaltegger et al. (1997) \\
\hline & Oceanic granite & 500 & Müller et al. (1996) \\
\hline \multirow[t]{2}{*}{ Tauern Window } & Supra-subduction & Cambrian & Frisch and Neubauer (1989) \\
\hline & Basalts & $547 \pm 27$ & Eichhorn et al. (1999) \\
\hline Habach terrane & Mafic-ultramafic cumulates & $496-482$ & Eichhorn et al. (2001) \\
\hline \multirow[t]{4}{*}{ Tauern Window South } & Eclogite protolith & 488 & Von Quadt et al. (1997) \\
\hline & $\mathrm{N}$-Morb intra-oceanic arc & $590 \varepsilon N d 6.9$ & Schulz et al. (2004) \\
\hline & Arc basalt & $550-530 \varepsilon \mathrm{Nd}-.3+2.5$ & \\
\hline & Metagabbro & 477 & Loth et al. (2001) \\
\hline Oetztal & Metagabbro, ultramafics & $530-521$ & Miller and Thöni (1995) \\
\hline Southern Alps & Eclogites HP event & $457 \pm 5,443 \pm 19$ & Franz and Romer (2007) \\
\hline
\end{tabular}


Table 1 continued

\begin{tabular}{llll}
\hline Terrane & Rock-type & Age (Ma) & References \\
\hline $\begin{array}{l}\text { 6. Saxothuringian } \\
\text { Vesser area }\end{array}$ & MOR gabbro & & Kemnitz et al. (2002) \\
Münchberg Klippe & Eclogiteic metagabbro & 501.7 & Gebauer and Grünenfelder \\
Erbendorf-Hohenstrauss & Metagabbro & (1979) & Von Quadt (1990) \\
7. Bohemian Massif & & & \\
Letovice Complex & Tholeiitic metabasalt & $494 \pm 3$ & Soejono et al. (2010) \\
Marianske Lasné & Coronitic metagabbro & & Stedra et al. (2002) \\
& Oceanic crust protolith & $530 \pm 6$ & Timmermann et al. (2004) \\
& Coronitic metagabbro & $516-496$ & Timmermann et al. (2006) \\
Tepla-Barrandian unit & Smrzovice meta-quartzdiorite & $\sim 540$ & Bues et al. (2002) \\
& Leucotonalite pebble & 503,496 & Smala et al.Sláma et al. (2008) \\
& Volcanic rocks & $\sim 550 \mathrm{~K}-\mathrm{Ar} \mathrm{Hbl}$ & Dörr et al. (2002) \\
& Metarhyolite & $610 \pm 17$ & Źák et al. (2013a, b) \\
& Epidote-amphibolite & $568 \pm 3$ & Teipel et al. (2004) \\
Bavarian Forest & Eclogitic amphibolite & $524 \pm 8.8$ & Teipel et al. (2004) \\
\hline
\end{tabular}

Presented $\varepsilon N d$ ages already may reflect alteration (Schaltegger et al. 2002). The authors recognize that many of the observed metabasic units in the Variscan mountain chain still wait for identification, needing future investigations. Consult references for analytical data

allochthonous complexes would represent the most external margin of Gondwana, constituted by Ediacaran to Cambrian terrigenous sequences, intruded by calc-alkaline to peralkaline granitoids and minor mafic rocks dated at around 510-470 Ma (Abati et al. 2010; Díez Fernández et al. 2010).

In the southern allochthonous Morais domain, Dias da Silva et al. (2012) brought the first evidence for a Late Cambrian bimodal Mora volcanic suite, observed at its base.

In the subjacent Central Iberian basement, andesitic volcanics testify to a Neoproterozoic-earliest Cambrian synsedimentary magmatism (Rodríguez Alonso et al. 2004), supposed to be closely related to the subduction of the Ossa Morena Zone.

South Armorican domain

Following Ballèvre et al. (2014), the metabasic units in the Bay d'Audierne domain have an Ordovician age and, together with the Champtoceaux and Essarts areas, could possibly host Ediacaran-Cambrian basic to ultrabasic rock suites (Fig. 1a).

\section{French Massif Central}

Strongly metamorphosed relics of Late Neoproterozoic to Early Palaeozoic oceanic rock suites were supposed to be part of the Upper Gneiss Unit (Ledru et al. 1989; Faure et al. 2009), being interpreted to represent an Early Ordovician continental break-up (Pin 1990; Pin and Marini 1993;
Santallier 1994). Specifically, the Limousin area presents features of an early magmatic evolution (Lardeaux et al. 2001; Berger et al. 2005, 2010, 2012), hosting relics of a former pre-Cambrian to Cambrian oceanic crust, equally discussed for the Maures Massif (Bellot et al. 2010). Ultrahigh-pressure relics dated about $412 \mathrm{Ma}$ in the Limousin area (Berger et al. 2010) may represent a lower Devonian intra-oceanic subduction event before the general Early Variscan HP evolution around 380 Ma (comp. Stampfli et al. 2013, their Figs. 7, 4-5).

\section{Saxothuringian Zone and Bohemian Massif}

These basements were object of a general re-interpretation (Franke 2000; Friedl et al. 2004; Schulmann et al. 2009, 2014; Žák et al. 2014). After the Cadomian accretionary evolution (Linnemann et al. 2007, 2008), Lower to Middle Cambrian rift basins in the Saxothuringian Zone resulted in an oblique incision of an oceanic ridge into the continent (Linnemann et al. 1998), and the Vesser ultramafic body (501 Ma, Kemnitz et al. 2002) preceded the opening of the Rheic Ocean (Tremadoc). The Münchberg eclogitic metagabbro ( $\sim 500 \mathrm{Ma}$, Table 1$)$ was tectonically related to the Bohemian Teplá-Barrandian Zone (Franke 2000).

The Teplá-Barandian unit in the Bohemian Massif (Hajná et al. 2013; Sláma et al. 2008; Žák et al. 2013b; Zulauf et al. 1999) testifies to Cadomian island-arc volcanism (620-560 Ma) and subsequent (560-530 Ma) arc erosion, before crustal extension since $510 \mathrm{Ma}$ and backarc-type opening of the Prague basin contemporaneous to 
the opening of the Rheic Ocean with basic submarine volcanism (Table 1). The Mariánské Lázně complex is characterized by large mafic-dominated Cambro-Ordovician bimodal series (e.g. Crowley et al. 2002; Floyd et al. 2000; Stedra et al. 2002) with N-MORB to within-plate alkali basalts. Bues et al. (2002) and Teipel et al. (2004) dated Ediacarian magmatism in the western Teplá-Barrandian Zone (Table 1).

The Brunovistulian unit in the south-east of the Bohemian Massif hosts a distinctly older assemblage of rock units with different types of metabasic rocks representing the Avalonian margin of the rock series under discussion in this paper (Finger et al. 2000).

\section{Alpine terrane assemblages}

Following Neubauer's (2002) comparative paper, Schulz (2008) reported from distinct Austroalpine domains (comp. Table 1) a rather long-lasting magmatic evolution, comprising intra-oceanic arcs (metadiorites around $610 \mathrm{Ma}$; N-MORB-type eclogitic metabasalts around $590 \mathrm{Ma}$ ), subsequent $550-530 \mathrm{Ma}$ volcanic arc basalts and 520-530 Ma eclogitized gabbroic and tonalitic melts intruding a continental (Gondwana) margin magmatic arc. These were followed by $500 \mathrm{Ma}$ oceanic plagiogranites in a supposed fore- or back-arc environment and the subsequent intrusion of gabbroic melts (475 Ma) in a collisional to post-collisional context. Sartori et al. (2006) and Scheiber et al. (2014) suggest an extensional Neoproterozoic-Cambrian evolution for the Briançonnais Siviez-Mischabel type basement. Equally, in the lower Penninic nappes (Schaltegger et al. 1997; Bussien et al. 2011), Early Cambrian metadiorites $(533,544 \mathrm{Ma})$ from a banded mafic complex and Cambrian ( $518 \mathrm{Ma})$ oceanic magmatism as dismembered relics of mafic and ultramafic rocks testify to a Cambrian magmatic evolution dominated by metabasic magmatic rocks. For the South Alpine Strona-Ceneri Zone, an upper Ordovician HP evolution is discussed (Zurbriggen et al. 1997; Franz and Romer 2007), with an upper Ordovician orogenic evolution for this area (Zurbriggen 2014). An Ordovician orogenic evolution has also been proposed for the external parts of the Alps (Schaltegger et al. 2003). Supposed EdiacaranCambrian meta-volcanic series from the Aiguilles Rouges basement (von Raumer et al. 2013; external alpine basement) can be compared to nearly identical lithostratigraphies from the Central Iberian basement (Rodríguez Alonso et al. 2004). The "root-less" Alpine ultramafic Chamrousse ophiolite complex from the external domain (Belledonne, Ménot et al. 1988) represents an allochthonous Late Cambrian magmatic body involved in the Variscan tectonic evolution (Guillot et al. 2009).

\section{Discussion}

Summarizing the data (Table 1), an Ediacaran to Cambrian age group $(\sim 650-510 \mathrm{Ma})$ is documented through intra-oceanic dismembered sequences, representing an early magmatic arc (Ossa Morena, SaxothuringianTeplá Barandian Units, Austroalpine domains), which accreted over a period of time to form a Cambrian periGondwana cordillera (Fig. 2). The Ossa Morena and the Teplá-Barrandian domains areas (see preceding chapter) show some interesting parallels when considering their more or less synchronous rifting-type subsidence patterns (Von Raumer and Stampfli 2008). The observations of widely distributed sedimentary horizons hosting amphibolites in the Ossa Morena Zone (Sánchez Lorda et al. 2014), probably former Ediacaran arc basalts, and possibly also in the Bohemian Massif (Hajná et al. 2013) reinforce these parallels. Comparable arc volcanics are known from the Austroalpine domain (Schulz et al. 2004) and compose also the Penninic Briançonnais basement nappes (Sartori et al. 2006). The Siviez-Mischabel and Mont Fort nappes (Escher 1988) represent parts of different types of basement, the former could represent the Ediacaran arc, intruded by Late Cambrian gabbros and granitoids (Bussy et al. 1996, and in Sartori et al. 2006), whereas the latter may comprise a suture zone (serpentinites, mélange type) of Ordovician age (comp. Gauthiez et al. 2011). The pre-Rheic igneous evolution ended apparently with a period of crustal extension along the Gondwana margin, accompanied by the emplacement of c. 500 Ma mafic to granitoid rocks: "where in a scenario of oblique convergence, pullapart may have facilitated the appearance of ophiolites, accompanied laterally by incomplete intra-oceanic rock suites, or simply by volcanic rocks and/or detrital sediments" (Von Raumer et al. 2002, p. 45), strike-slip models having been evoked since Murphy and Nance (1989). Reconstruction of cross sections (Fernández-Suárez et al. 2014; Zulauf et al. 1999; Schulz et al. 2004; Linnemann et al. 2007; Sánchez Martínez et al. 2012; Žák et al. 2013a; Ballèvre et al. 2014) present intra-cordillera rifting at lower crustal level triggering the upwelling of asthenosphere, leading to back-arc rifting during the Early Ordovician. Similarly, in the Saxothuringian basin (Linnemann et al. 2014), a synrift sequence from the Tremadoc onwards is supposed to accompany the opening of the Rheic Ocean, and in the Prague basin, it is accompanied by basic submarine volcanism (Patočka et al. 1994; Žák et al. 2013b). The South Armorican units could have formed in a comparable context, as Ordovician igneous rocks (Table 1) seem to represent the main Early Palaeozoic manifestation. 


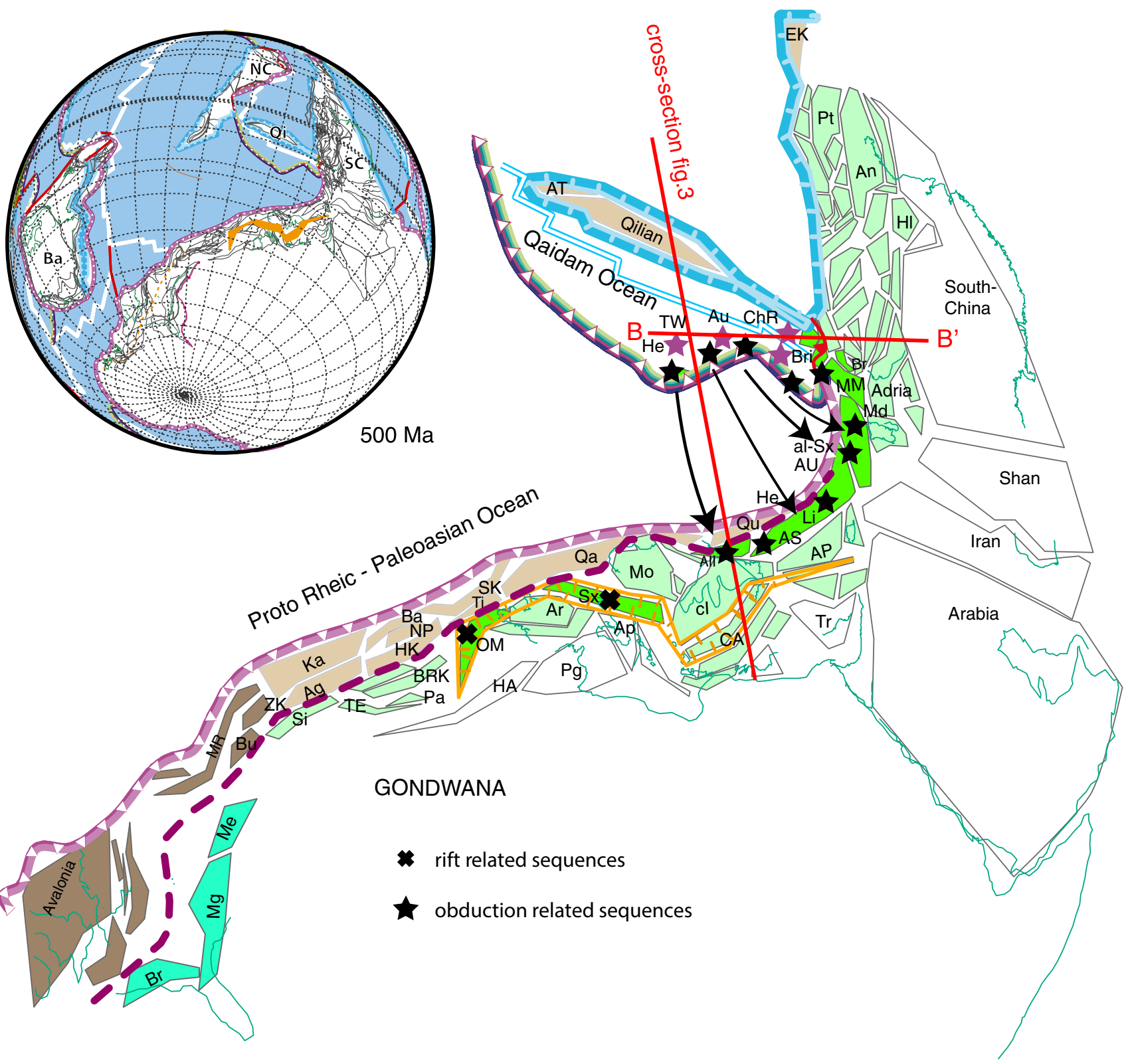

Fig. 2 Cambrian (500 Ma) plate-tectonic reconstruction (modified after Stampfli et al. 2011). Stars (black and violet) Magmatic rocks as meta-eclogites, Crosses Cambrian rift-related magmatic rocks. The future break-up of the Rheic Ocean is marked as a dashed purple line. a Inset Geodynamic units along the Gondwana margin, presented in detail in b Geodynamic units along the Gondwana margin. Light brown Hunic terranes, future Chinese basement domains; Light green Central European. Variscan basements with domains (dark green) hosting allochthonous former proto-Rheic oceanic basements. Orange Rift zone with strong subsidence and accumulation of detrital sediments (comp. von Raumer and Stampfli 2008). Stars Magmatic rocks as meta-eclogites, crosses Cambrian rift-related magmatic

\section{Plate-tectonic considerations}

The existence of pre-Palaeozoic active margin sequences along the Gondwana margin has been discussed since rocks. B-B': Section 500 Ma in Fig. 4. QILIAN ARC: All Iberian Allocthomous, $a l-S x$ allochtonous Saxothuringian, $C h R$ Chamrousse. GALATIAN: $A r$ Armorica, $A u$ Austroalpine, $M d$ Moldanubian Teplá-Barrandian unit, $\mathrm{He}$ External massifs, $\mathrm{Li}$ Limousin, $O M$ Ossa Morena, $S x$ Saxothuringian, BRK Betic Rif Kabbylies, TE Tell East, Si Sidi, $\mathrm{Pa}$ Panormides. AVALONIA-HANSEATIC: $M R$ Mid-German Rise, $Z K$ Zonguldag-Kure, $B u$ Bukovina. GONDWANA: Ap Apulia, $H A$ High Atlas, $P g$ Pelagian, $\operatorname{Tr}$ Taurus. HUNIA: $A g$ Aghdarband, $A n$ Anarak, AT Altyn Tagh, $B a$ Badakshan, $E K$ East Kunlun, $H K$ Hindukush, Ka Karakum, NP North Pamir, Qa Qaidam, Qi Qilian, Qu Qinling, $S K$ South Kunlun, Ti Tianshuihal

Frisch and Neubauer (1989; Austroalpine gneiss-amphibolite association; Schulz et al. 2004). In view of their location at the margin border, Stampfli et al. (2011) proposed to correlate part of them with a pre-Rheic arc located in the 
Fig. 3 Geodynamic scenarios from the Late Cambrian to the Silurian across the future Alpine and adjacent domains at the Gondwana margin: from Late Cambrian arc-arc collision and subsequent back-arc obduction (480 Ma) along the Gondwana border. After subduction reversal, slab rollback is triggering the opening of the Rheic rift and Rheic Ocean (465 Ma) in eastern Gondwana. The arc-arc collision was diachronous, as well as the opening of the Rheic Ocean, both events taking place sooner westwards (c.10 Ma).

The different stages of "Armorican Quartzite I, II, III" are commented in the text
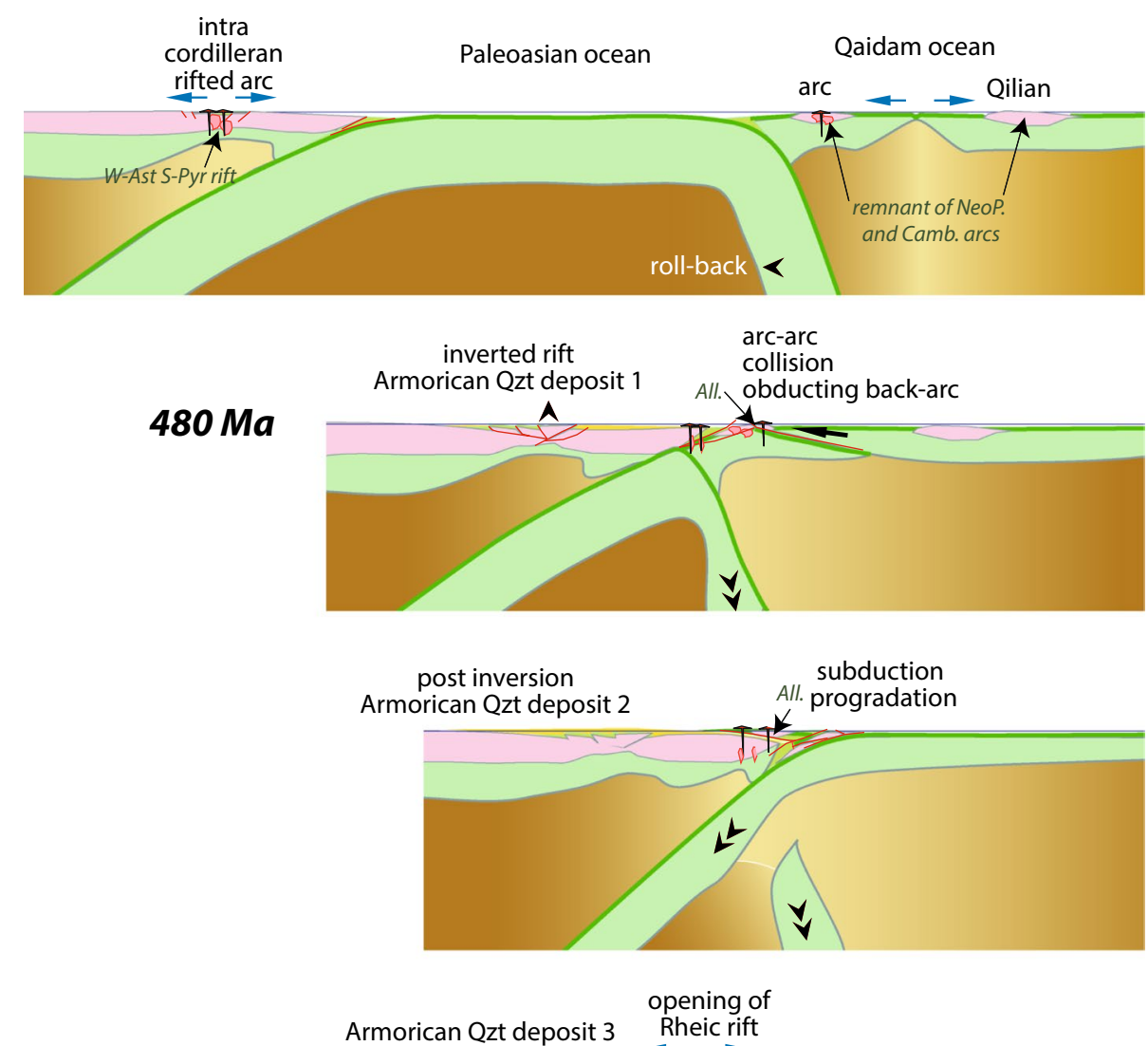

$465 \mathrm{Ma}$

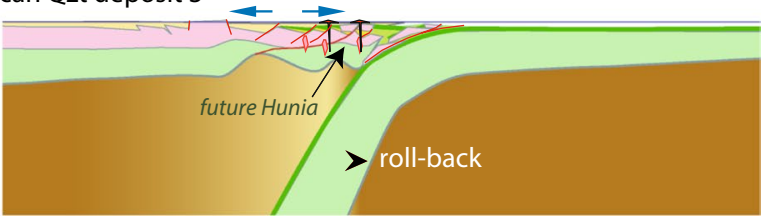

Palaeo-Asian Ocean. The exotic Qilian-Qaidam arc basement of Fig. 2 could possibly be derived from these eastern regions (Wilhem 2010; Wilhem et al. 2012; Stampfli et al. 2013) and would consist of a Cadomian type basement. Ridge jump detached a fragment of Qilian to form the Qaidam arc (Fig. 3) accreted to the Gondwana margin around $475 \mathrm{Ma}$. Potential remnants of this arc could be represented by arc sequences at the top of the Iberian nappe pile dated around $500 \mathrm{Ma}$. The presence of $500 \mathrm{Ma}$ plagiogranites (Chamrousse) could also be interpreted as derived from an intra proto-Rheic/Palaeo-Asian oceanic crust. Similarly, the Métailler formation of the Penninic domain (Sartori et al. 2006; Gauthiez et al. 2011) represents a potential post-Cambrian mélange of oceanic nature, comprising ultramafite, OIB, E-MORB and some carbonates. In this context, some mafic to ultramafic rock suites interpreted as related to intra-cordillera rifting (South Armorica, allochthonous Saxothuringian, parts of the Moldanubian) may have been derived from this exotic arc domain.

The topmost (Floian) Armorican Quartzite s.str. (Gutiérrez-Alonso et al. 2007; Shaw et al. 2012, 2014) in Iberia represents erosion of the rift shoulder of the opening Rheic Ocean; however, its base generally lies unconformably on a thick, folded, Late Precambrian to Cambrian turbidite sequence (McDougall et al. 1987) that we relate with the collision of the Gondwana active margin with the Qaidam arc, soon followed by the accretion of the Qilian block. Comparably, the Sardic tectonic phase (e.g. Martini et al. 1991) is of similar age and is found from Catalonia to the Montagne Noire and the nappe zone of Sardinia (Oggiano et al. 2010) where it marks the eastern limit of this Early Ordovician obduction event and related tectonic inversion of pre-existing rifts (Fig. 1).

The proposed cross-sectional model (Figs. 2, 3) is located at the junction between two types of setting. North of Africa the incoming Qaidam arc was most likely underplated and would have been removed by subsequent rifting of a relatively large (up to $500 \mathrm{~km}$ ) Hunia during the opening of the Rheic Ocean (Fig. 3), whereas, eastward, the arc-arc collision was followed by the obduction of the young and buoyant Qaidam supra-subduction ocean. Part of these obducted arc/back-arc sequences have been preserved along this 
Fig. 4 Early Palaeozoic geodynamic scenarios for the Alpine Briançonnais-Austroalpine basements and adjacent areas: from a Cambrian Gondwanan cordillera (500 Ma) to underplated arc and Sardic inverse folding (Sardic Phase $480 \mathrm{Ma}$ ), subsequent crustal extension (460 Ma), arc-arc oblique collision (450 Ma) and exhumation at a transform margin (430 Ma). Age data from Table 1 and from von Raumer et al. (2013)
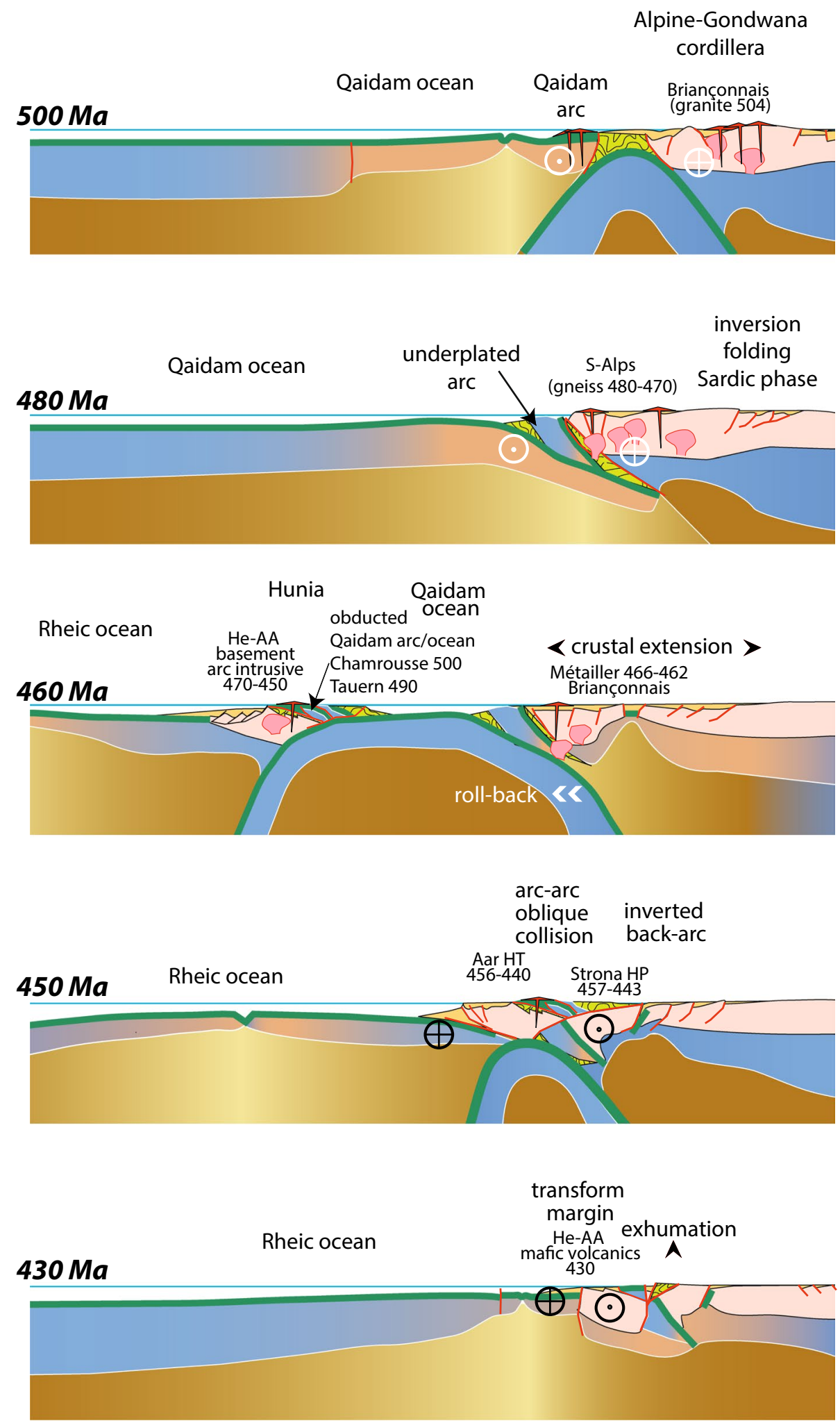

portion of the margin (from the allochtonous sequences of Spain to the Alpine domains) due to the removal of a relatively thin $(100 \mathrm{~km})$ Hunia ribbon terrane along that portion of the margin. The obducted sequences would then form the toe of the Gondwanan Rheic passive margin north of Spain, Ligeria and Moldanubian domains (palaeomagnetic data correspond to our Ordovician placing of the Prague basin, Patocka et al. 1994) after the opening of the Rheic Ocean. 
The internal part of the obducted arc (and its Cadomian substratum) was removed during the drifting of Hunia (violet stars of Figs. 1, 2) and re-accreted north-eastwards along the future transform margin west of S-China (Fig. 4). This scenario is confirmed by the presence of a Late Ordovician orogenic evolution (Zurbriggen et al. 1997; Zurbriggen 2014) involving fore-arc sequences in the StronaCeneri Zone (Southern Alps) with possible parallels in the Austroalpine (Schulz et al. 2004) and external domains. The dated eclogites and HP evolution in a subduction zone ( 457 Ma: Franz and Romer 2007: Strona-Ceneri Zone; Schaltegger et al. 2003: Helvetic domain) comprise mafic magmatism and resulted in crustal thickening from Early to Late Ordovician. The Métailler back-arc-type mafic rocks (Gauthiez et al. 2011) are interpreted here as a witness of a short-lived back-arc basin within the margin west of S-China, in view of its age too young to pertain to the Qaidam back-arc complex. After the Strona-Ceneri tectonic event, this "Alpine" domain margin became a passive transform margin, in which basic rocks were intruded at the passage of the Rheic mid-ocean ridge during the Silurian. This margin was also affected by a first phase of Paleo-Tethys rifting during that period that aborted in the Early Devonian (Stampfli et al. 2013). Most of the Alpine basement blocks are therefore regarded as pertaining to Hunia (cf. Schulz et al. 2004), before to be detached from Gondwana in the Devonian to form the large Galatian ribbon terrane.

When comparing structures along the Gondwana margin (Von Raumer et al. 2014), it becomes evident that structures observed at the eastern end of the Gondwana margin cannot directly be compared to the westernmost ones, where the main suture is supposed to represent mainly the amalgamation of Gondwana through Cadomian events (Murphy et al. 2006; Linnemann et al. 2008). The provenance of the involved basements may have had their origin in northern China or in north-eastern Baltica, and the suture is likely of Ediacaran (540-530 Ma) age. Eastern equivalents may be found in more eastern Variscan basement blocks, but the proximity of Panafrican and Cadomian sutures prevented any distinction so far.

The eastern Gondwana margin, the subject of this paper, contains Sardic and Strona type sutures in addition to older Cadomian, Panafrican ones which are related to the colliding Qaidam arc with Gondwana (African and Alpine type basements), and the drifting of Hunia, which occurred when Avalonia was already separated from Gondwana.

Location in the Variscan nappe pile

The allochthonous units (Fig. 2) found in the Variscan nappe pile underwent an HP event well established around $390 \mathrm{Ma}$ in the whole Variscan chain (Abati et al. 2010; Ballèvre et al. 2009; Faryad and Kachlík 2013; Godard
2009; Lardeaux et al. 2001; Lucks et al. 2002; Stampfli et al. 2002). Diverging points of view regard that event either as an early collision between Gondwana and Laurussia (Matte 2002, and references therein; Arenas et al. 2014), or as peri-Gondwanan (Stampfli et al. 2013, and reference therein). The Cambro-Ordovician oceanic relics that remained on the Gondwana passive margin of the Rheic have certainly been re-displaced and locally metamorphosed during this c. 410-390 Ma obduction/collision event (e.g. Timmermann et al. 2004; Berger et al. 2010) and also during younger Variscan HP-HT events (Abati et al. 2007; Fernández-Suárez et al. 2007) when Galatian blocks started to collide with each other (Stampfli et al. 2013). The main Variscan collision started around $360 \mathrm{Ma}$, locally accompanied by HP metamorphism (Maluski and Patočka 1997), and complex nappe structures were formed until the final closure of the Rhenohercynian Ocean in the Late Carboniferous. Therefore, the final juxtaposition of allochtonous units hosting Early Palaeozoic oceanic relics with other Variscan units is certainly not representative of their original position and still needs to be properly re-assessed.

The collision of these Variscan terranes with Laurasiaderived terranes (Hanseatic) started the Variscan cycle of collision s.str. In this context, the $390 \mathrm{Ma}$ event is regarded as Early Variscan and peri-Gondwanan. The Variscan collision started around $360 \mathrm{Ma}$, and complex nappe structures were formed until the final closure of the Rhenohercynian Ocean in the Late Carboniferous.

Summary and conclusion

The preceding chapters demonstrate the presence of an Ediacaran-Cambrian active margin setting along the Gondwana margin (Figs. 2, 3). Despite local differences, the basement areas under consideration must have evolved continuously and in a more or less cylindrical way during this earlier time period, resulting in the building of a cordillera along the Gondwana margin. But different to the sutures observed in the more western domains (Murphy et al. 2006; Linnemann et al. 2008), those of the eastern Gondwana margin, including the sectors from Iberia and Ossa Morena to the Bohemian Massif and the Eastern Alps, host younger Ordovician sutures in which older structures were preserved (Fig. 4). This diversified evolution is related to a possible juxtaposition of China-derived blocks and intra-oceanic arcs of the Palaeo-Asian/proto-Rheic Ocean with parts of this eastern Gondwana margin (see earlier discussion, von Raumer et al. 2002).

These eastern sectors of the Gondwana margin document the emplacement of Late Cambrian metabasic, ultrabasic or granitoid rocks possibly related to extensional environment of different origins. The thickened crust of the ageing Gondwanan cordillera may have collapsed more 
easily, also due to accelerating rollback as exotic terranes approached the margin in Early Cambrian times. Gabbros in intra-cordillera rifts had their contemporaneous counter parts in the exotic Qaidam domain due to rollback of the same Palaeo-Asian Ocean, resulting in the opening of Late Cambrian supra-subduction back-arc basins.

Arc-arc collision and opening of the Rheic Ocean were diachronous along the Gondwana margin. The cross sections of Fig. 3 characterize a more eastern location (see Fig. 2), where a Late Cambrian arc-arc collision was followed by back-arc obduction (480 Ma). Subsequent subduction reversal triggered the rifting and opening of the Rheic Ocean (465 Ma) as the Hun terrane left the eastern Gondwana margin.

For the Alpine Briançonnais-Austroalpine basements and adjacent areas, the sections (Fig. 4) depict after the Sardic tectonic inversion and folding stage (Sardic phase $480 \mathrm{Ma}$ ), a younger arc-arc oblique collision ( $450 \mathrm{Ma}$ ) of the eastern tail of the Hun terrane with the internal Alpine margin, followed by exhumation in a transform margin setting $(430 \mathrm{Ma})$.

We conclude that parallels of a pre-Rheic magmatic evolution in the different Variscan allochthonous ophiolitic basement areas is evident. Presenting relics of former Ediacaran to Cambrian arcs, part of them could include remnants of intra-oceanic proto-Rheic/Palaeo-Asian arcs/backarcs, before they were accreted to the Gondwana margin and before the opening of the Rheic Ocean. Time parallels with more western Neoproterozoic sutures (comp. Murphy et al. 2006) are evident, but differences appear in the more eastern Gondwana margin, where the evolution terminated with Late Ordovician suturing. The postulated obduction/ collision event (c. $390 \mathrm{Ma}$ ) and the subsequent Variscan orogenic evolution explain the final tectonic situation of these ophiolitic sequences. We are conscious that much more detail research has to be performed for reconstituting the original pre-Cambrian to Ordovician plate-tectonic configurations, and it was only our intention to stimulate discussion for coming research.

Acknowledgments We acknowledge the constructive comments by Jiří Žák (Prague) on an earlier version of this paper, Fritz Finger (Salzburg) is thanked for careful comments and suggestions, and we are grateful to the Editor in Chief Wolf Christian Dullo for his understanding help. RA and SSM have been funded by the Spanish project CGL2012-34618. Walter Joyce (Fribourg) is thanked for English proof reading.

\section{References}

Abati J, Dunning GR, Arenas R, Díaz García F, Gonzáles Cuadra P, Martínez Catalán JR, Andonaegui P (1999) Early Ordovician orogenic event in Galicia (NW Spain): evidence from U-Pb ages in the uppermost unit of the ordenes complex. Earth Planet Sci Lett 165:213-228
Abati J, Castiñeiras P, Arenas R, Fernández-Suárez J, Gómez Barreiro J, Wooden J (2007) Using SHRIMP-RG U-Pb zircon dating to unravel tectonomagmatic events in arc environments. The early Paleozoic arc of NW Iberia revisited. Terra Nova 19:432-439

Abati J, Gerdes A, Fernández-Suárez J, Arenas R, Whitehouse MJ, Díez Fernández R (2010) Magmatism and early-Variscan continental subduction in the northern Gondwana margin recorded in zircons from the basal units of Galicia, NW Spain. Geol Soc Am Bull 122:219-235

Andonaegui P, Castiñeiras P, González Cuadra P, Arenas R, Sánchez Martínez S, Abati J, Díaz García F, Martínez Catalán JR (2012) The Corredoiras orthogneiss (NW Iberian Massif): geochemistry and geochronology of the Paleozoic magmatic suite developed in a peri-Gondwanan arc. Lithos 128-131:84-99

Arenas R, Martínez Catalán JR, Abati J, Sánchez-Martinez S (2007a). The rootless Variscan suture of NW Iberia (Galicia, Spain). Field trip guide and abstracts. IGCP 497 Galicia meeting 2007, La Coruña, Spain, Instituto Geológico y Minero de España, p $1-118$

Arenas R, Martínez Catalán JR, Sánchez Martínez S, FernándezSuárez J, Andonaegui P, Pearce JA, Corfu F (2007b) The Vila de Cruces ophiolite: a remnant of the early Rheic Ocean in the Variscan suture of Galicia (NW Iberian Massif). J Geol 165:129-148

Arenas R, Díez Fernández R, Sánchez Martínez S, Gerdes A, Fernández-Suárez J, Albert R (2014) Two-stage collision: exploring the birth of Pangea in the Variscan terranes. Gondwana Res 25:756-763

Ballèvre M, Bosse V, Ducassou D, Pitra P (2009) Palaeozoic history of the Armorican Massif: models for the tectonic evolution of the suture zones. C R Geosci 341:174-201

Ballèvre M, Martínez Catalán JR, López-Carmona A, Pitra P, Abati J, Díez Fernández R, Ducassou C, Arenas R, Bosse V, Castiñeiras P, Fernández-Suárez J, Gómez Barreiro J, Paquette JL, Peucat JJ, Poujol M, Ruffet G, Sánchez Martínez S (2014) Correlation of the nappe stack in the Ibero-Armorican arc across the Bay of Biscay: a joint French-Spanish project. In: Schulmann K, Martínez Catalán JR, Lardeaux JM, Janousek V, Oggiano G (eds) The Variscan orogeny: extent, timescale and the formation of the European crust, vol 405. Geological Society of London, pp 77-113 (Spec Publ). doi:10.1144/SP405.13

Bellot JP, Laverne C, Bronner G (2010) An early Palaeozoic suprasubduction lithosphere in the Variscides: new evidence from the Maures massif. Int J Earth Sci (Geol Rundsch) 99:473-504

Berger J, Féménias O, Mercier JCC, Demaiffe D (2005) Ocean-floor hydrothermal metamorphism in the Limousin ophiolites (western French Massif Central): evidence of a rare preserved Variscan oceanic marker. J Metam Geol 23:795-812

Berger J, Féménias O, Ohnenstetter D, Bruguier O, Plissart G, Mercier JC, Demaiffe D (2010) New occurrence of UHP eclogites in Limousin (French Massif Central): age, tectonic setting and fluid-rock interactions. Lithos 118:365-382

Berger J, Féménas O, Mercier JC, Ohnenstetter D, Bruguier D (2012) Ophiolite and eclogites from Limousin (French Massif Central): keys to Variscan subduction processes. Géol Fr 2012:65-66

Bues C, Dörr W, Fiala J, Vejnar Z, Zulauf G (2002) Emplacement depths and radiometric ages of Paleozoic plutons of the Neukirchen-Kdyne massif: differential uplift and exhumation of Cadomian basement due to Carboniferous orogenic collapse (Bohemian Massif). Tectonophysics 352:225-243

Bussien D, Bussy F, Magna T, Masson H (2011) Timing of Palaeozoic magmatism in the Maggia and Sambucco nappes and paleogeographic implications (Central Lepontine Alps). Swiss J Geosci 104:1-29

Bussy F, Derron MH, Jacquod J, Sartori M, Thélin Ph (1996) The 500-Ma old Thyon metagranite: a new A-type granite 
occurrence in the western Penninic Alps (Wallis, Switzerland). Eur J Miner 8:565-575

Cambeses A, Scarrow JH, Montero P, Molina JE, Moreno JA, Bea F (2014) A rifted volcanic margin, Red Sea type branch model for the Ossa-Morena Zone during the Cambro-Ordovician. Abstract Volume, Instituto Geologico y Minero de España, Madrid, 2014

Cavargna-Sani M, Epard JL, Bussy F, Ulianov A (2014) Basement lithostratigraphy of the Adula Nappe: implications for Palaeozoic evolutionand Alpine kinematics. Int J Earth Sci (Geol Rundsch) 113:61-82

Chichorro M, Pereira MF, Díaz-Azpiroz M, Williams IS, Fernández C, Pin C, Silva JB (2008) Cambrian ensialic rift-related magmatism in the Ossa-Morena Zone (Évora-Aracena metamorphic belt, SW Iberian Massif): Sm-Nd isotopes and SHRIMP zircon U-Th-Pb geochronology. Tectonophysics 461:91-113

Crowley Q, Floyd PA, Stedra V, Winchester JA, Kachlik V, Holland G (2002) The Marianske-Lazne Complex, NW Bohemian Massif: development and destruction of an early Palaeozoic seaway. In: Winchester JA, Pharaoh TC, Verniers J (eds) Palaeozoic amalgamation of Central Europe, vol 201. Geological Society of London, pp 177-193 (Spec Publ)

Dias da Silva I, Valverde Vaquero P, Gonzáles Clavijo E, Díez Montes A, Martínez Catalán JR (2012) Structural and stratigraphical significance of $\mathrm{U}-\mathrm{Pb}$ ages from the Saldanha and Mora volcanic complexes (NE Portugal, Iberian Variscides). Special meeting of French and Italian Geological Societies, Sassari. Géologie de France 1:105-106

Díez Fernández R, Martínez Catalán JR, Gerdes A, Abati J, Arenas R, Fernández-Suárez J (2010) U-Pb ages of detrital zircons from the basal allochthonous units of NW Iberia: provenance and paleoposition on the northern margin of Gondwana during the Neoproterozoic and Paleozoic. Gondwana Res 18:385-399

Eichhorn R, Höll R, Loth G, Kennedy A (1999) Implications of U-Pb SHRIMP zircon data on the age and evolution of the Felbertal tungsten deposit (Tauern Window, Austria). Int J Earth Sci (Geol Rundsch) 88:496-512

Eichhorn R, Loth G, Kennedy A (2001) Unravelling the pre-Variscan evolution of the Habach terrane (Tauern Window, Austria) by U-Pb SHRIMP zircon data. Contrib Mineral Petrol 142:147-162

Escher A (1988) Structure de la nappe du Grand Saint-Bernard entre le Val de Bagnes et les Mischabel. Rapp Géol Serv Hydrol et Géol Natl (Berne) 7:1-26

Faryad SW, Kachlík V (2013) New evidence of blueschist facies rocks and their geotectonic implication for Variscan suture(s) in the Bohemian Massif. J Metamorph Geol 31:63-82

Faure M, Lardeux JM, Ledru P (2009) A review of the pre-Permian geology of the Variscan French Massif Central. C R Geosci 341:202-213

Fernández-Suárez J, Arenas R, Abati J, Martínez Catalán JR, Whitehouse MJ, Jeffries TE (2007) U-Pb chronometry of polymetamorphic high-pressure granulites: an example from the allochthonous terranes of the NW Iberian Variscan belt. In: Hatcher Jr RD, Carlson MP, McBride JH, Martínez Catalán JR (eds) 4-D framework of continental crust, vol 200. Geological Society of America Memoris, pp 469-488

Fernández-Suárez J, Guttiérrez-Alonso G, Pastor-Galán D, Hofmann M, Murphy JB, Linnemann U (2014) The Ediacaran-Early Cambrian detrital zircon record of NW Iberia: possible sources and and paleogeographic constraints. Int J Earth Sci (Geol Rundsch) 103:1335-1357

Finger F, Hanžl P, Pin C, von Quadt A, Steyrer HP (2000) The Brunovistulian: Avalonian Precambrian sequence at the eastern end of the Central European Vaiscides? In: Franke W, Altherr, R, Haak V, Oncken O, Tanner D (eds) Orogenic processes-quantification and modelling in the Variscan belt of Central Europe, vol 179. Geological Society of London, pp 103-112 (Spec Publ)

Floyd PA, Winchester J, Seston R, Kryza R, Crowley QG (2000) Review of geochemical variation in lower Palaeozoic metabasites from the NE Bohemian Massif: intracratonic rifting and plume-ridge interaction. In: Franke W, Altherr, R, Haak V, Oncken O, Tanner D (eds) Orogenic processes-quantification and modelling in the Variscan belt of Central Europe, vol 179. Geological Sociey of London, pp 155-174 (Spec Publ)

Franke W (2000) The mid european segment of the Variscides: tectono-stratigraphic units, terrane boundaries and plate tectonic evolution. In: Franke W, Altherr, R, Haak V, Oncken O, Tanner $\mathrm{D}$ (eds) Orogenic processes-quantification and modelling in the Variscan belt of Central Europe, vol 179. Geological Society of London, pp 35-62 (Spec Publ)

Franz L, Romer R (2007) Caledonian high-pressure metamorphism in the Strona-Ceneri-Zone (Southern Alps of southern Switzerland and northern Italy). Swiss J Geosci 100:457-467

Friedl G, Finger F, Paquette JL, von Quadt A, McNaughton NJ, Fletcher IR (2004) Pre-Variscan geological events in the Austrian part of the Bohemian Massif deduced from U-Pb zircon ages. Int J Earth Sci (Geol Rundsch) 93:802-823

Frisch W, Neubauer F (1989) Pre-Alpine terranes and tectonic zoning in the eastern Alps. In: Dallmeyer RD (ed) Terranes in the circum-Atlantic Paleozoic orogens, vol 230. Geological Society of America, pp 91-114 (Spec Publ)

Gauthiez L, Bussy F, Ulianov A, Gouffon Y, Sartori M (2011) Ordovician mafic magmatism in the Métailler Formation of the MontFort nappe (Middle Penninic domain, western Alps)—geodynamic implications, vol 9. In Abstract of Swiss Geoscience Meeting, Zürich, p 110-111

Gebauer D, Grünenfelder M (1979) U-Pb zircon and Rb-Sr mineral dating of eclogites and their country rocks. Example: Münchberger Gneiss Massif, northeast Bavaria. Earth Planet Sci Lett 42:35-44

Sánchez Lorda MF, Eguiluz L, Ábalos B, Garcia de Madinabeitia S, Gil Ibarguchi, JI (2014a) U-Pb geochronological evidence for Ediacaran arc-related magmatism in the Ossa-Morena Zone (SW Iberia). Abstract Gondwana 15 Madrd

Godard G (2009) Two orogenic cycles recorded in eclogite-facies gneiss from the southern Armorican Massif (France). Eur J Miner 21:1173-1190

Guillot S, Ménot RP (2009) Paleozoic evolution of the external crystalline massifs of the Western Alps. Comptes Rendus de l'Académie des Sciences 341:253-265

Gutiérrez-Alonso G, Fernández-Suárez J, Gutiérrez-Marco JC, Corfu F, Murphy JB, Suárez Martinez S (2007) U-Pb depositional age for the upper Barrios Formation (Armorican Quartzite facies) in the Cantabrian zone of Iberia: implications for stratigraphic correlation and paleogeography, In: Linnemann U, Nance RD, Kraft P, Zulauf G (eds) The evolution of the Rheic Ocean: from Avalonian-Cadomian active margin to Alleghenian-Variscan collision, vol 423. Geological Society of America, pp 287-296 (Spec Paper)

Hajná J, Žák J, Kachlík V, Dörr W, Gerdes A (2013) Neoproterozoic to early Cambrian Franciscan-type mélanges in the Teplá-Barrandian unit, Bohemian Massif: evidence of modern-style accretionary processes along the Cadomian active margin of Gondwana? Precambrian Res 224:653-670

Herbig HG, Aretz M (2013) The Mississippian of the Jerada massif (NE Morocco)-more northwest European than Palaeotethyan affinities. Schriftenreihe der Deutschen Gesellschaft für Geowissenschaften 82:50

Kalvoda J, Bábek O (2010) The Margins of Laurussia in central and southeast Europe and southwest Asia. Gondwana Res 17:526-545 
Kemnitz H, Romer R, Oncken O (2002) Gondwana break-up and the northern margin of the Saxothuringian belt (Variscides of Central Europe). Int J Earth Sci (Geol Rundsch) 91:246-259

Kroner U, Romer RL (2013) Two plates - many subduction zones: the variscan orogeny reconsidered. Gondwana Res 24:298-329

Lardeaux JM, Ledru P, Daniel I, Duchene S (2001) The Variscan French Massif Central - a new addition to the ultrahigh pressure metamorphic "club": exhumation processes and geodynamic consequences. Tectonophysics 332:143-167

Lardeaux JM, Schulmann K, Faure M, Janoušek V, Skrzypek E, Lexa O, Edel JB, Stípská P (2014) The Moldanubian Zone in the French Massif Central, Vosges/Schwarzwald and Bohemian Massif revisited: differences and similarities. In: Schulmann K, Martínez Catalán JR, Lardeaux JM, Janoušek V, Oggiano G (eds) The Variscan orogeny: extent, timescale and the formation of the European Crust, vol 405. Geological Society of London, pp 7-44 (Spec Publ)

Ledru P, Lardeaux JM, Santallier D, Autran A, Quenardel JM, Floc'h JP, Lerouge G, Maillet N, Marchand J, Ploquin A (1989) Où sont les nappes dans le Massif central français? Bull Soc Geol Fr 5(3):605-618

Linnemann U, Gehmlich M, Tichomirova M, Buschmann B, Bombach K (1998) Tectonostratigraphic events of the Peri-Gondwanan basement of the Saxo-Thuringian composite terrane (Central European Variscides). Schriften des Staatlichen Museums für Mineralogie und Geologie, Dresden 9:159-161

Linnemann U, Gerdes A, Drost K, Buschmann B (2007) The continuum between Cadomian orogenesis and opening of the Rheic Ocean: Constraints from LA-ICP-MS U-Pb zircon dating and analysis of plate-tectonic setting (Saxo-Thuringian zone, northeastern Bohemian Massif, Germany). In: Linnemann U, Nance D, Kraft P, Zulauf G (eds) The Evolution of the Rheic Ocean: From Avalonian-Cadomian active margin to AlleghenianVariscan collision. vol 423. Geological Society of America, pp 61-96 (Spec Publ)

Linnemann U, Pereira F, Jeffries TE, Drost K, Gerdes A (2008) The Cadomian Orogeny and the opening of the Rheic Ocean: the diacrony of geotectonic processes constrained by LA-ICP-MS $\mathrm{U}-\mathrm{Pb}$ zircon dating (Ossa-Morena and Saxo-Thuringian Zones, Iberian and Bohemian Massifs). Tectonophysics 461:21-43

Linnemann U, Gerdes A, Hofmann M, Marko L (2014) The Cadomian orogen: neoproterozoic to Early Cambrian crustal growth and orogenic zoning along the periphery of the West AfricanCraton-Constraints from U-Pb zircon ages and $\mathrm{Hf}$ isotopes (Schwarzburg Antiform, Germany). Precambrian Res 244:236-278

Loth G, Eichhorn R, Höll R, Kennedy A, Schauder P, Söllner F (2001) Cambro-Ordovician age of a metagabbro from the Wildschönau ophiolite complex, Greywacke Supergroup (Eastern Alps, Austria): a U-Pb-SHRIMP study. Eur J Miner 13:566-577

Lucks H, Schulz B, Audren C, Triboulet C (2002) Variscan pressuretemperature evolution of garnet pyroxenites and amphibolites in the Baie d'Audierne metamorphic series, Brittany (France). In: Martínez Catalán JR, Hatcher RD, Jr, Arenas R, Díaz García F (eds) Variscan-Appalachian dynamics: the building of the late Paleozoic basement, vol 364. Geological Society of America, pp 89-103 (Spec Publ)

Maluski H, Patočka F (1997) Geochemistry and 40Ar/39Ar geochronology of the mafic metavolcanic rocks from the Ry'chory Mountains complex (west Sudetes, Bohemian Massif): palaeotectonic significance. Geol Ma 134:703-716

Martínez Catalán JR, Arenas R, Abati J, Sánchez Martínez S, Díaz García F, Fernández Suárez J, González Cuadra P, Castiñeiras P, Gómez Barreiro J, Díez Montes A, González Clavijo E, Rubio Pascual FJ, Andonaegui P, Jeffries TE, Alcock JE, Díez Fernández R, López Carmona A (2009) A rootless suture and the loss of the roots of a mountain chain: the Variscan belt of NW Iberia. C R Geosci 341:114-126

Martini IP, Tongiorgo M, Oggiano G, Cocozza T (1991) Ordovician alluvial fan to marine shelf transition in SW Sardinia, Western Mediterranean Sea: tectonical ("Sardic Phase") influenced clastic sedimentation. Sediment Geol 72:97-115

Matte P (2002) Variscides between the Appalachians and the Urals: similarities and differences between Paleozoic subduction and collision belts. Geol Soc Am Spec P 364:239-251

McDougall N, Brenchley PJ, Rebelo JA, Romano M (1987) Fans and fan deltas-precursors to the Armorican Quartzite (Ordovician) in western Iberia. Geol Mag 124:347-359

Ménot RP, Peucat JJ, Scarenzi D, Piboule M (1988) 496 My age of plagiogranites in the Chamrousse ophiolite complex (external crystalline massifs in the French Alps): evidence of a lower Paleozoic oceanization. Earth Planet Sci Lett 88:82-92

Miller Ch, Thöni M (1995) Origin of eclogites from the Austroalpine Ötztal basement (Tirol, Austria): geochemistry and Sm-Nd vs $\mathrm{Rb}-\mathrm{Sr}$ isotope systematics. Chem Geol 122:199-225

Müller B, Klötzli U, Schaltegger U, Flisch M (1996) Early Cambrian oceanic plagiogranite in the Silvretta nappe eastern Alps: geochemical, zircon $\mathrm{U}-\mathrm{Pb}$ and $\mathrm{Rb}-\mathrm{Sr}$ data from garnet-hornblende-plagioclase gneisses. Geol Rundsch 85:822-831

Murphy JB, Nance RD (1989) Model for the evolution of the Avalonian-Cadomian belt. Geology 17:735-738

Murphy JB, Gutiérrez-Alonso G, Nance RD, Fernandez-Suárez J, Keppie JD, Quesada C, Strachan RA, Dostal J (2006) Origin of the Rheic Ocean: rifting along a Neoproterozoic suture? Geology $34: 325-328$

Nance RD, Gutiérrez-Alonso G, Keppie JD, Linnemann U, Murphy JB, Quesada C, Strachan RA, Woodcock NH (2010) Evolution of the Rheic Ocean. Gondwana Res 17:194-222

Neubauer F (2002) Evolution of late Neoproterozoic to early Paleozoic tectonic elements in Central and Southeast European Alpine mountain belts: review and synthesis. Tectonophysics 352:87-103

Oberli F, Meier M, Biino G (1994) Time constraints on the pre-Variscan magmatic/metamorphic evolution of the Gotthard and Tavetsch units derived from single-zircon $\mathrm{U}-\mathrm{Pb}$ results. Schweiz Mineral Petrogr Mitt 74:483-488

Oggiano G, Gaggero L, Funedda A, Buzzi L, Tiepolo M (2010) Multiple early Paleozoic volcanic events at the northern Gondwana margin: U-Pb age evidence from the southern Variscan branch (Sardinia, Italy). Gondwana Res 17:44-58

Patočka F, Galle A, Vavrdová M, Vlašímský P (1994) Early Paleozoic evolution of the Barrandian terrane, Bohemian massif, Czech Republic: paleotectonic implications of sedimentary, fossil and volcanic record. J Czech Geol Soc 39:82-83

Pereira MF, Solá AR, Chichorro M, Lopes L, Gerdes A, Silva BA (2012) North-Gondwana assembly, break-up and paleogeography: $\mathrm{U}-\mathrm{Pb}$ isotope evidence from detrital and igneous zircons of Ediacaran and Cambrian rocks of SW Iberia. Gondwana Res 22:866-881

Pin Ch (1990) Variscan Oceans—ages, origins and geodynamic implications inferred from geochemical and radiometric data. Tectonophysics 177:215-227

Pin Ch, Carme Ch (1987) A Sm-Nd isotopic study of 500 Ma old oceanic crust in the Variscan belt of Western Europe: the Chamrousse ophiolite complex, Western Alps (France). Contrib Mineral Petrol 96:406-413

Pin Ch, Lancelot J (1982) U-Pb dating of an early Paleozoic bimodal magmatism in the French Massif Central and of its further metamorphic evolution. Contrib Mineral Petrol 79:1-12

Pin Ch, Marini F (1993) Early Ordovician continental break-up in Variscan Europe: $\mathrm{Nd}-\mathrm{Sr}$ isotope and trace element evidence from bimodal igneous associations of the Southern Massif Central, France. Lithos 29:177-196 
Poller U (1997) U-Pb single zircon study of gabbroic and granitoid rocks of Val Barlas-ch (Silvretta nappe, Switzerland). Schweiz Mineral Petrogr Mitt 77:351-359

Rodríguez Alonso MD, Peinado M, López-Plaza M, Franco P, Carnicero A, Gonzalo JC (2004) Neoproterozoic-Cambrian synsedimentary magmatism in the Central Iberian Zone (Spain): geology, petrology and geodynamic significance. Int J Earth Sci (Geol Rundsch) 93:897-920

Roper RA, Arenas R, Gerdes A, Sánchez Martínez S (2013) Refined ages of magmatism and high-P metamorphism in the eclogite facies gneiss formation of the Cabo Ortegal Complex. Schriftenreihe der Deutschen Gesellschaft für Geowiss 82:93

Sánchez Lorda MF, Sarrionandia F, Ábalos B, Carracedo M, Eguiluz L, Gil Ibarguchi JI (2014) Geochemistra and paleotectonic setting of Ediacaran metabasites from the Ossa Morena Zone (SW Iberia). Int J Earth Sci (Geol Rundsch) 103:1263-1286

Sánchez Martínez S, Gerdes A, Arenas R, Abati J (2012) The Bazar Ophiolite of NW Iberia: a relic of the Iapetus-Tornquist Ocean in the Variscan suture. Terra Nova 24:283-294

Sánchez-García T, Quesada C, Bellido F, Dunning GR, González del Tánago J (2008) Two-step magma flooding of the upper crust during rifting: the Early Paleozoic of the Ossa Morena Zone (SW Iberia). Tectonophysics 461:72-90

Sánchez-García T, Bellido F, Pereira MF, Chichorro M, Quesada C, Pin Ch, Silva JB (2010) Rift-related volcanism predating the birth of the Rheic Ocean (Ossa-Morena zone, SW Iberia). Gondwana Res 17:392-407

Santallier DS (1994) The Massif Central. Introduction. In: Keppie JD (ed) Pre-Mesozoic geology in France and related areas. Springer, Berlin, pp 267-275

Sartori M, Gouffon Y, Marthaler M (2006) Lithostratigraphie des unités briançonnaises en Valais. Eclogae Geol Helv 99:363-407

Schaltegger U, Nägler TN, Corfu F, Maggetti M, Galetti G, Stosch H (1997) A Cambrian island arc in the Silvretta nappe: constraints from geochemistry and geochronology. Schweizerische Mineralogische und Petrographische Mitteilungen 77:337-350

Schaltegger U, Gebauer D, von Quadt A (2002) The mafic-ultramafic rock association of Loderio-Biasca (lower Pennine nappes, Ticino, Switzerland): Cambrian oceanic magmatism and its bearing on early Paleozoic paleogeography. Chem Geol 186:265-279

Schaltegger U, Abrecht J, Corfu F (2003) The Ordovician orogeny in the Alpine basement: constraints from geochronology and geochemistry in the Aar Massif (Central Alps). Schweiz Mineral Petrogr Mitt 83:183-195

Scheiber T, Berndt J, Mezker K, Pfiffner OA (2014) Precambrian to Paleozoic zircon record in the Siviez-Mischbel basement (western Swiss Alps). Swiss J Geosci 107:49-64

Schulmann K, Konopasek J, Janousek V, Lexa O, Lardeaux JM, Edel JB, Stipska P, Ulrich S (2009) An Andean type Palaeozoic convergence in the Bohemian massif. C R Geosci 341:266-286

Schulmann K, Martínez Catalán JR, Lardeaux JM, Janoušek V, Oggiano G (eds) (2014) The Variscan Orogeny: extent, timescale and the formation of the European Crust. Geological Society of London, vol 405. Geological Society of London (Spec Publ)

Schulz B (2008) Basement of the Alps. In: McCann T (ed) Geology of Central Europe. Precambrian and Paleozoic, vol 1. Geological Society of London, p 79-83

Schulz B, Bombach K, Pawlig S, Braetz H (2004) Neoproterozoic to Early-Palaeozoic magmatic evolution in the Gondwana-derived Austroalpine basement to the south of the Tauern Window (Eastern Alps). Int J Earth Sci (Geol Rundsch) 93:824-843

Shaw J, Johnston S, Gutiérrez-Alonso G, Weil AB (2012) Oroclines of the Variscan orogen of Iberia: Paleocurrent analysis and paleogeographic implications. EPSL 329-330:60-70
Shaw J, Gutiérrez-Alonso G, Johnston S., Pastor Galán D (2014) Provenance variability along the early Ordovician north Gondwana margin: Paleogeographic and tectonic implications of $\mathrm{U}-\mathrm{Pb}$ detrital zircon ages from the Armorican Quartzite of the Iberian Variscan belt. Geological Society of Amererica Bulletin. Online 13 Feb 2014. doi:10.1130/B30935.1

Sláma J, Dunkley DJ, Kachlík V, Kusiak MA (2008) Transition from island-arc to passive setting on the continental margin of Gondwana: U-Pb zircon dating of Neoproterozoic metaconglomerates from the SE margin of theTeplá-Barrandian Unit, Bohemian Massif. Tectonophysics 461:44-59

Soejono I, Zácková E, Janoušek V, Machek M, Košler J (2010) Vestige of an Early Cambrian incipient oceanic crust incorporated in the Variscan orogen: letovice complex, Bohemian Massif. J Geol Soc Lond 167:1113-1130

Stampfli GM, von Raumer J, Borel G (2002) The Paleozoic evolution of pre-Variscan terranes: from Gondwana to the Variscan collision. Geol Soc Am Spec Publ 364:263-280

Stampfli GM, von Raumer J, Wilhem C (2011) The distribution of Gondwana derived terranes in the early Paleozoic. In: Gutiérrez-Marco JC, Rábano I, García-Bellido D (eds) The Ordovician of the world, Cuadernos del Museo Geominero, Instituto Geológico y Minero de España, Madrid 14:567-574

Stampfli GM, Hochard C, Vérard C, Wilhem C, von Raumer J (2013) The geodynamics of Pangea formation. Tectonophysics 593:1-19

Stedra V, Kachlik V, Kryza R (2002) Coronitic metagabbros of the Marianské Lázné Complex and Tepla Crystalline Unit: inferences for the tectonometamorphic evolution of the western margin of the Teplá-Barrandian Unit, Bohemian Massif. In: Winchester JA, Pharaoh TC, Verniers J (eds) Palaeozoic amalgamation of Central Europe, vol 20. Geological Society of London, pp 217-236 (Spec Publ)

Stille P, Tatsumoto M (1985) Precambrian tholeiitic-dacitic rocksuites and Cambrian ultramafic rocks in the Penninic nappe systems of the Alps: evidence from Sm-Nd isototpes and rare earth elements. Contrib Mineral Petrol 89:184-192

Teipel U, Eichorn R, Loth G, Rohrmüller J, Höll R, Kennedy A (2004) U-Pb SHRIMP and Nd isotopic data from the western Bohemian Massif (Bayerischer Wald, Germany): implications for upper Vendian and lower Ordovician magmatism. Int J Earth Sci (Geol Rundsch) 93:782-801

Timmermann H, Štědrá V, Gerdes A, Noble SR, Parrish RR, Dörr W (2004) The problem of dating high-pressure metamorphism: a $\mathrm{U}-\mathrm{Pb}$ Isotope and geochemical study on eclogites and related rocks of the Mariánské Lázně Complex, Czech Republic. J Petrol 45:1311-1338

Timmermann H, Dörr W, Krenn E, Finger F, Zulauf G (2006) Conventional and in situ geochronology of the Tepla Crystalline unit, Bohemian massif: implications for the processes involving monazite formation. Int J Earth Sci (Geol Rundsch) 95:629-648

Von Quadt A (1990) U-Pb zircon and SM-Nd analysis on metabasites from the KTB pilote bore hole. KTB Rep 90(4):545

Von Quadt A, Günther D, Frischknecht R, Zimmermann R, Franz $\mathrm{G}$ (1997) The evolution of pre-Variscan eclogites of the Tauern Window (Eastern Alps): a Sm/Nd- conventional and Laser ICP-MS zircon U-Pb study. Schweiz Mineral Petrogr Mitt 77:265-279

Von Raumer J, Stampfli GM (2008) The birth of the Rheic Oceanearly Palaeozoic subsidence patterns and tectonic plate scenarios. Tectonophysics 461:9-20

Von Raumer J, Stampfli GM, Borel GD, Bussy F (2002) The organization of pre-Variscan basement areas at the Gondwana margin. Int J Earth Sci (Geol Rundsch) 91:35-52

Von Raumer J, Bussy F, Schaltegger U, Schulz B, Stampfli GM (2013) Pre Mesozoic Alpine basements-their place in the European Paleozoic framework. GSA Bull 125:89-108 
Von Raumer J, Stampfli GM, Arenas R, Sánchez-Martínez S (2014) The Cambro-Ordovician Gondwana margin in Europe. Abstract. Gondwana 15, Madrid. Abstract Volume, p 172, Instituto Geologico y Minero de Espana, Madrid

Wilhem C (2010) Plate Tectonics of the Altaids. Dissertation: University of Lausanne, Switzerland

Wilhem C, Windley B, Stampfli GM (2012) The Altaids of Central Asia: a tectonic and evolutionary innovative review. Earth Sci Rev 113:303-341

Žák J, Kraft P, Hajná J (2013a) Timing, styles, and kinematics of Cambro-Ordovician extension in the Teplá-Barrandian Unit, Bohemian Massif, and its bearing on the opening of the Rheic Ocean. Int J Earth Sci (Geol Rundsch) 102:415-433

Žák J, Zulauf G, Dörr W, Hajná J, Verner K (2013b) From Cadomian accretion to Variscan collision: a crustal-scale traverse across the northwestern Teplá-Barrandian unit. Schriftenreihe der Deutschen Gesellschaft für Geowiss 82:119-149

Žák J, Verner K, Janoušek V, Holub FV, Kachlík,V, Finger F, Hajná J, Tomek F, Vondrovic L, Trubač J (2014) A plate-kinematic model for the assembly of the Bohemian Massif constrained by structural relationships around granitoid plutons. In: Schulmann K, Martínez Catalán JR, Lardeaux JM, Janoušek V, Oggiano G (eds) The Variscan Orogeny: extent, timescale and the formation of the European crust, vol 405. Geological Society of London, pp 169-196 (Spec Publ)

Zulauf G, Schitter F, Riegler G, Finger F, Fiala J, Vejnar Z (1999) Age constraints on the Cadomian evolution of the Teplá Barrandian unit (Bohemian Massif) through electron microprobe dating of metamorphic monazite. Z dt Geol Ges 150:627-639

Zurbriggen R (2014) Ordovician orogeny in the Alps: a reappraisal. Int J Earth Sci (Geol Rundsch). doi:10.1007/s00531-014-1090-x

Zurbriggen R, Franz L, Handy M (1997) Pre-Variscan deformation, metamorphism and magmatism in the Strona-Ceneri Zone (southern Alps of Northern Italy and southern Switzerland). Schweiz Mineral Petrogr Mitt 77:361-381 